\title{
オキナワをめぐる戦後と冷戦を問う
}

孫知延著『戦後才キナワ文学を思惟する方法一ジェンダ、エスニック、 そしてナショナルアイデンティティ』(召命出版, 2020年)

Hyoungduck KWAK (郭烟德: Assistant Professor of Dept. of Japanese Language and Literature Myongji University) 凶kwak202@gmail.com

(韓国) 明知大学校日語日文学科。助教授。戦時期の日本文学からはじめ、現在は戦後日本のマイ ノリティーに注目する研究を進めている。『金史良と日本帝国主義末期の植民地文学』(ソウル：召命 出版、2017)、『才キナワ文学選集』(ソウル：召命出版、2020)、『大東亜文学者大会会議録』(ソウ ル：召命出版, 2019)など。

\section{An Analysis of the Post-war Conditions of Okinawa and the Effects of the Cold War on the Island}

Son Jiyon's "Contemplating Post-War Okinawan Literature : Gender, Ethnicity, and National Identity" criticizes the East Asian framework for understanding, and delves deeply into the intersection of postwar conditions and the Cold War in relation to Okinawa, through an analysis of various texts. As the author suggests, the situation of Okinawa is a microcosm of wider problems that are prevalent in the consciousness of East Asia as a whole, and which therefore can be understood at a fundamental level by Koreans, because they overlap with the contradictions thrown up by war and division in South Korea.

Keywords Okinawan Literature, Oshiro Tatsuhiro, East Asian Writers 
韓国でオキナワ文学が本格的に翻訳されてから十年以上の年月が経った。その間、さまざま なオキナワ文学選集が出され、研究書としても『二つの島：抵抗の両極、韓国と沖縄』(李明元 著、サムチャン、2017)や『沖縄を読む：戦後の沖縄文学と思想』(趙正民著、召命出版、2017)な どが刊行された。2020年に刊行された孫知延の『戦後オキナワ文学を思惟する方法』はこれらの 研究書と同じようにオキナワ文学を日本だけではなく、東アジアという枠組みの中で問うてい る。ただ、本書は東アジア自体を媒介にその枠組み自体に強くこだわっている。本書に収めら れている佐藤泉との対談の中で東アジアを日本の帝国主義が作り出した秩序であると同時に、 その負の遺産を受け継いだ反共産主義のブロックとして定義する箇所は東アジアの両義性を語 る上で重要な指摘である。冷戦が解体された後、「東アジア」は脱冷戦の言説として浮上した が、帝国主義の残影が色濃く残されていたからである。ただ、本書の意義は東アジアの傷痕を 可視化させたところにあるというよりは、類似性を強調しすぎてないところにある。言い換え れば、韓国とオキナワの類似した歴史を意識しつつも、それに包摂されず、日本本土とオキナ ワ、そして韓国とオキナワ、済州島とオキナワの戦後と冷戦の交差を著者は緻密に読み取って いる。その中でも「戦後と冷戦、そして「占領とジェンダ」は本書の最も重要なキーワードであ る。

\section{1 戦後と冷戦}

最近「戦後ゼロ年」という用語が日本のテレビでよく使われている。この時の戦後という時 間・空間を生きた人々は秩序のない世界ではあるものの新しい生活への希望に満ちている。ま さに本土の戦後である。本土において「戦後ゼロ年」とは廃壚となった国土を民衆のエネルギー によって復興させはじめた起点として語られる。しかし、オキナワにおいて「戦後ゼロ年」と は戦後を数えることはできないと言う存立不可能性を語る場合に用いられる。目取真俊は『沖縄 「戦後」ゼロ年 (生活人新書)』(NHK出版, 2005)において戦後がオキナワで存在してなかったとい う意味で「戦後」ゼロ年」という概念を持ち出す。本土とオキナワにおいて真逆の意味で使われ る「戦後ゼロ年」は、ナショナル・ヒストリーによって忘却されたマイノリティーの苦痛の時間 と空間を想起させる。ただ、著者はその「忘却」自体ではなく、それを可能にした「冷戦」と「戦 後」の関わりに集中して論を展開している。

著者は第一部と第二部、「辺境の記憶」と「アイデンティティの交錯の場」の中で、本土とオキ ナワにおいて敗戦と戦後が如何に違ったかをさまざまな例をあげながら論証する。著者はオキ ナワにおける敗戦の空間を「国家」なき「敗戦」空間」として定義し、本土を中心とする国家中心 の敗戦空間論を批判する。「「国家」なき「敗戦」空間」を生きるウチナーンチュにおいてもっとも 切実に感じられたのはアイデンティティのより所であった。著者は第二部において日本とアメ リカ、そして沖縄の間で摇れる彼・彼女らのアイデンティティを、大城立裕の初期小説とうち なーぐちの使い方を中心に深く読み取っている。 


\section{2 占領とジェンダ}

本書のもう一つの軸は占領とジェンダの関わり方である。第三部「ジェンダで読むオキナワ の占領叙事」を貫く問題意識は敗戦と占領によってもたらされた男性たちの屈折された心理と女 性の貞操をめぐって繰り返される国家的なレべルでの貞操観念の復活である。著者は菊池寛の 「貞操について」において「進駐軍」に性を売る日本人女性を䎵として批判していることに注目 し、「未亡人」・「国家」・目性」の問題が戦後においてより強力な「国家的な母性」の創出につな がっていると指摘する。そして戦後文学において描かれた「国家的な危機二女性の性的危機」の 中にアメリカによって占領されたオキナワとオキナワ女性の危機が徹底的に隠蔽されているこ とまで論を展開する。さらに、著者は戦後オキナワ文学者たちが一特に大城立裕の「カクテ ル・パーティー」と「ニライカナイの街」において一女性の身体(性と貞操)の毀損を「米軍の暴力 的な占領システム」を想起させるジェンダ表象として配置していることを鋭く指摘する。

一方、著者は「復帰」以降のジェンダ表象の反転を中原晋の「銀のオートバイ」、下川博の「ロ スからの愛の手紙、喜舎場直子の「女綾織唄」の中で見出す。1970年代後半から米軍とオキナワ 人女性の関係は加害者と被害者という二項対立を超えて、相互的な関係へと変貌された。著者 は復帰以降の小説の中に「オキナワ人女性の「内面」が描かれ始めたのはもっとも重要な変化」だ とし、ジェンダ表象の反転を意味づける。特に、「ジェンダ構図自体がアメリカと日本本土、

しそてオキナワの間の政治」と深く関わっていることを論証している点は重要である。

このように孫知延の『戦後オキナワ文学を思惟する方法』は東アジアという枠組み自体を批評 しながら、オキナワをめぐる戦後と冷戦の交差をさ まざまなテキストを通して深く分析している。それ は著者自らが問うているように、それが単にオキナ ワだけの問題ではなく、韓国における戦争と分断の矛 盾と重なっているからこそ、実感と想像できた問題意 識であるように思われる。著者は「オキナワ社会が直 面した特殊な事情を東アジアという同時性の中で把握 し、それをジェンダやエスニック、そしてアイデン ティティという三つのスペクトラム」を通して解釉し ようとしたと「はじめに」の中で書き記している。こ こでは第四部「オキナワ戦闘と済州四・三、そして記 憶闘争」と第五部「東アジアの平和と連帯に向からオキ ナワ文学」には具体的にふれてないが、本書は著者の 意図を超えて「東アジアという同時性」より広く読者に 実感させている。本書によって韓国におけるオキナ ワ文学研究は日本文学研究という領域を超えて学際的 研究に跳躍したと言えよう。

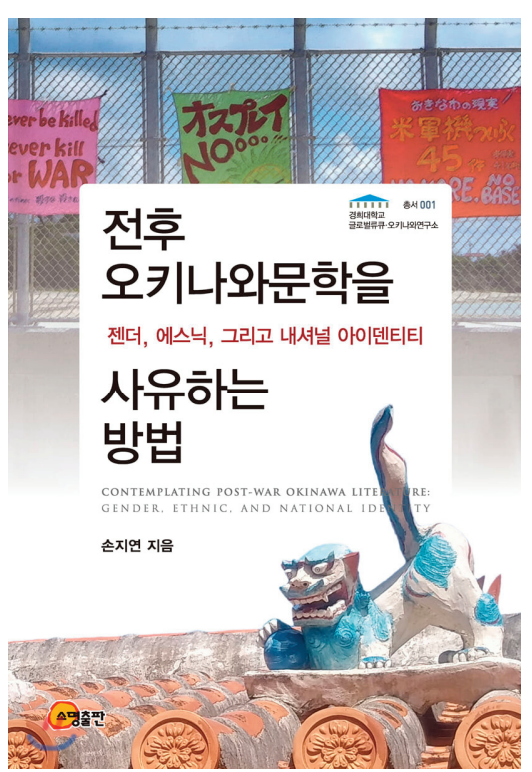

『戦後才キナワ文学を思惟する方法一ジェンダ、 エスニック、そしてナショナルアイデンティティ』 (2020.4) 